\title{
33. PRELIMINARY ORGANIC GEOCHEMICAL STUDIES OF DSDP CORES, LEG 42B, BLACK SEA
}

\author{
Vassil T. Vuchev, ${ }^{1}$ Chavdar P. Ivanov, ${ }^{2}$ Marija St. Kabakchieva,' Ljuben L. Petrov, ${ }^{1}$ \\ Rossitsa Zh. Stojanova, ${ }^{2}$ Dechko D. Stephanov, ${ }^{1}$ Dechka N. Djakova, ${ }^{2}$ and Lilija K. Petrova ${ }^{2}$
}

\section{INTRODUCTION}

The following report contains the preliminary results of the organic geochemical studies carried out on six samples from the cores of Hole 379A and Site 381, Leg 42B, drilled by $\mathrm{D} / \mathrm{V}$ Glomar Challenger during its research operations in the Black Sea during May and June 1975. The studies were done in two parts. The first included both organic matter and mineral components of the sediments, which were analyzed by the Organic Geochemistry and other laboratories of the Geological Institute, Bulgarian Academy of Sciences. The second part of the studies included total nitrogen determination and identification of amino acids in the sediments, which was done by the Department of Organic Chemistry, Higher Institute of Chemical Technology, Sofia. Differential thermal analysis of the noncarbonate and bitumoid-free mineral components was obtained, under vacuum, by $\mathrm{Ph}$. Zakharieva and X-ray examinations were done by $D$. Stephanov. These studies represent the first participation of the Bulgarian scientific laboratories in the Deep Sea Drilling Project.

\section{MATERIALS AND METHODS}

Our samples came from the same core intervals as those chosen for organic geochemistry analysis, and were collected by Dr. John Hunt onboard ship. The samples were frozen for shipping, but thawed during transportation. In the laboratory they were refrozen and stored before final study.

The sediment samples were selected from a midPleistocene section of Site 381 and Hole 379A, in the Black Sea (Tables 1 and 2).

Each analysis was done on fresh portions of the samples. For the first part of the analysis, the samples were dried under vacuum $\left(40^{\circ} \mathrm{C}\right.$ and $25 \mathrm{~cm} \mathrm{Hg}$ pressure) to constant weight, lasting about 400 hours. The following procedures were then applied.

1) Determination of the authigenic-mineralogical forms of iron was made. A part of a sample was treated with $10 \% \mathrm{HCl}$ to determine $\mathrm{Fe}^{2+}$ and $\mathrm{Fe}^{3+}$; this solubilizes both $\mathrm{Fe}^{2+}$ and $\mathrm{Fe}^{3+}$ but does not influence $\mathrm{Fe}_{\text {pyr. }}^{2+} \mathrm{Fe}^{2+}$ was determined by means of titration with $\mathrm{KMnO}_{4}$ of known normality. The content of $\mathrm{Fe}^{2+}$ is calculated as:

\footnotetext{
'Geological Institute, Bulgarian Academy of Sciences, 1113 Sofia, Bulgaria.

${ }^{2}$ Department of Organic Chemistry, Higher Institute of Chemical Technology, 1156 Sofia, Bulgaria.
}

$$
\left[\mathrm{Fe}^{2+}(\%)=\frac{\text { normality of } \mathrm{KMnO}_{4} \times \mathrm{ml} \mathrm{KMnO}_{4} \times 0.05584 \times 100}{\text { weight of the sample }}\right]
$$

In the remaining aliquatic portion of the solution, $\mathrm{Fe}^{2+}$ was converted to $\mathrm{Fe}^{3+}$ with $\mathrm{H}_{2} \mathrm{O}_{2}$ and $\mathrm{Fe}^{3+}$ was precipitated as $\mathrm{Fe}(\mathrm{OH})_{3}$ with $\mathrm{NH}_{4} \mathrm{OH}$; the precipitate was filtered and then ignited up to $950^{\circ} \mathrm{C}$. $\mathrm{Fe}^{3+}$ was determined gravimetrically as $\mathrm{Fe}_{2} \mathrm{O}_{3}$, according to the expression:

$$
\mathrm{Fe}^{2+}+\mathrm{Fe}^{3+}(\%)=\frac{\text { weight of } \mathrm{Fe}_{2} \mathrm{O}_{3} \times 0.6994 \times 100}{\text { weight of the sample }}
$$

The remaining insoluble portion of the sample was treated with $24 \% \mathrm{HCl}$ to dissolve $\mathrm{Fe}_{\mathrm{pyr}}^{2+}$, which then was determined gravimetrically as $\mathrm{Fe}_{2} \mathrm{O}_{3}$.

The value of the total iron content corresponds to the sum:

$$
\mathrm{Fe}_{\text {total }}(\%)=\mathrm{Fe}^{2+}+\mathrm{Fe}^{3+}+\mathrm{Fe}_{\mathrm{pyr}}^{2+} \text {, }
$$

representing therefore the bulk of the authigenic iron in the sediments.

2) X-ray diffraction analysis was performed using Kristallofleks IV Siemens diffractometer and camera (Stephanov et al., 1968). The sediments, being calcareous muds, were treated with $5 \% \mathrm{CH}_{3} \mathrm{COOH}$ to remove carbonates. Clay minerals were identified by

\begin{tabular}{|c|c|c|c|}
\hline $\begin{array}{l}\text { Site } \\
\text { and } \\
\text { Hole }\end{array}$ & Core & $\begin{array}{l}\text { Interval } \\
(\mathrm{m})\end{array}$ & Lithology \\
\hline $381^{\mathrm{a}}$ & 19 & $171.0-180.5$ & $\begin{array}{l}\text { Mud, greenish gray to } \\
\text { dark gray, calcareous }\end{array}$ \\
\hline 381 & $19 a$ & $171.0-180.5$ & $\begin{array}{l}\text { Mud, greenish gray to } \\
\text { dark gray, calcareous }\end{array}$ \\
\hline $379 A^{b}$ & 31 & $282.5-292.0$ & $\begin{array}{l}\text { Mud, dark greenish gray } \\
\text { calcareous, terrigenous }\end{array}$ \\
\hline 381 & 32 & $285.0-294.5$ & $\begin{array}{l}\text { Mud, olive-gray calca- } \\
\text { reous, diatomaceous }\end{array}$ \\
\hline 381 & 34 & $304.0-313.5$ & Mud, olive-gray marly \\
\hline $379 \mathrm{~A}$ & 51 & $463.0-472.5$ & Mud, dark greenish gray \\
\hline \multicolumn{4}{|c|}{ 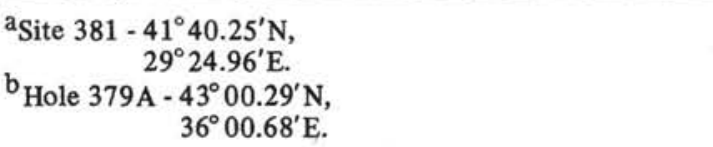 } \\
\hline
\end{tabular}

TABLE 1

General Information of the Core Samples Studied 
TABLE 2

Organic Geochemical Data of the Cores (in wt \% of Dry Sample)

\begin{tabular}{|c|c|c|c|c|c|c|c|c|c|}
\hline \multirow[b]{2}{*}{ Core } & \multirow{2}{*}{$\begin{array}{l}\text { Noncarbonate } \\
\text { Content } \\
\text { (NC) } \\
(\%)\end{array}$} & \multirow[b]{2}{*}{$\begin{array}{l}\mathrm{C}_{\text {org }} \\
(\%)\end{array}$} & \multirow[b]{2}{*}{$\begin{array}{c}\mathrm{C}_{\text {org }}^{\text {an }} \\
(\%)\end{array}$} & \multirow{2}{*}{$\begin{array}{c}\text { Ethanol/ } \\
\text { Benzene } \\
\text { Bitumoid } \\
\text { (ETBB) } \\
(\%)\end{array}$} & \multirow{2}{*}{$\begin{array}{l}\text { Humic } \\
\text { Acids } \\
\text { (HA) } \\
(\%)\end{array}$} & \multirow{2}{*}{$\begin{array}{l}\mathrm{C}_{\text {org }}= \\
\mathrm{C}_{\text {org }}^{\text {an }}+\mathrm{C}_{(\%)}^{\text {bit }} \text { org }\end{array}$} & \multirow[b]{2}{*}{$\begin{array}{l}N \\
(\%)\end{array}$} & \multirow[b]{2}{*}{$\begin{array}{c}\operatorname{ETBB}(\mathrm{A}+\mathrm{C}) \\
(\%)\end{array}$} & \multirow{2}{*}{$\frac{\text { ETBB. } 100}{\underset{(\%)}{\operatorname{ETBB}(A+C)}}$} \\
\hline & & & & & & & & & \\
\hline 19 & 79.50 & 0.63 & 0.50 & 0.043 & - & 0.53 & 0.038 & 0.62 & 6.9 \\
\hline $19 a$ & 82.00 & 0.62 & 0.51 & 0.026 & 0.0026 & 0.53 & 0.039 & 0.71 & 3.7 \\
\hline 31 & 88.20 & 0.58 & 0.51 & 0.077 & 0.0049 & 0.57 & 0.042 & 0.67 & 11.5 \\
\hline 32 & 90.29 & 1.76 & 1.59 & 0.230 & 0.0187 & 1.77 & 0.076 & 0.36 & 63.9 \\
\hline 34 & 64.70 & 1.35 & 0.87 & 0.104 & 0.0386 & 0.95 & 0.030 & 1.51 & 6.9 \\
\hline 51 & 84.20 & 0.33 & 0.28 & 0.025 & - & 0.30 & 0.058 & 0.41 & 6.1 \\
\hline
\end{tabular}

the behavior of basal reflections in the original sediment and in sediment saturated with glycerine and dimethylsulfoxide, heated up to $600^{\circ} \mathrm{C}$, and treated with warm $\mathrm{HCl}$.

3) DTA curves (Figure 1) were obtained on noncarbonate mineral residue derived from the pulverized and bitumoid-free samples, after treating with $5 \% \mathrm{HCl}$. The curves express the total effect of the mineral (mostly clay) composition of the sediments and their humic acids and kerogen contents. To reduce the influence of the last two components the analyses were performed under vacuum.

4) Extraction of bitumoids in Soxhlet apparatus, with ethanol/benzene 1:3 mixture, took 80 hours. To remove elemental sulfur and to precipitate the mineral salts, the bitumoids, in solvents, were consequently treated with activated copper and subjected to ethanol evaporation and replacement by benzene. Inorganic material including mineral particles was removed by filtration. The filtrate was stripped of solvent using a rotary evaporator at $60^{\circ} \mathrm{C}$ and taken to constant weight in a vacuum oven $\left(40^{\circ} \mathrm{C}\right.$ and $25 \mathrm{~cm} \mathrm{Hg}$ pressure). The content of bitumoids shown in Table 2 is in weight $\%$ of a dry sample. There are two bitumoids in the same table: ETBB which expresses the content of bitumoid extracted directly from the dry sample (bitumoid "A") and ETBB $(A+C)$ or free plus bound bitumoid, which represents the total bitumoid extracted after acidification for carbonate removal. In this case ETBB $(A+C)$ was taken from the sediments after removal of three

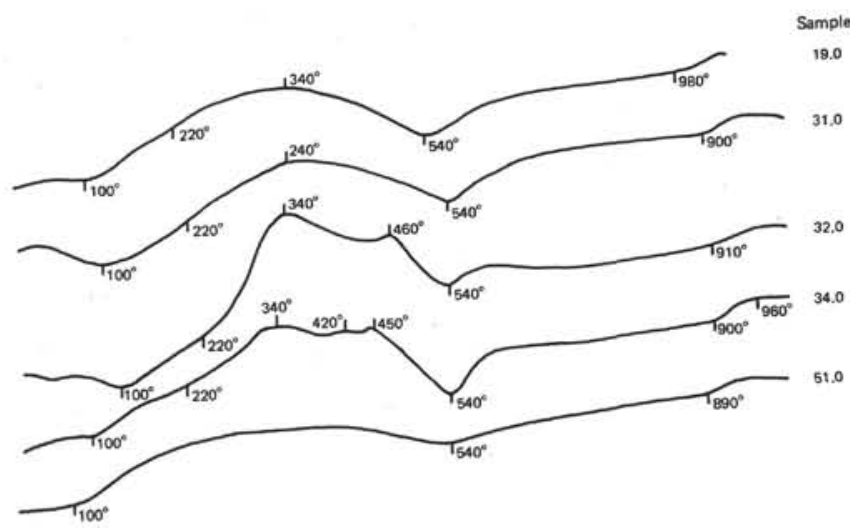

Figure 1. Thermograms of noncarbonate and bitumoid free mineral components of samples studied. extracts containing amino acids (Table 7) following procedures described in paragraph 11 of this section.

5) Column chromatographic separation of bitumoids was carried out using glass column of length $30 \mathrm{~cm}$ and diameter $1.5 \mathrm{~cm}$ filled with silica gel $\mathrm{BDH}$, 60-120 mesh usually activated. Bitumoid sample to adsorbent ratio is $1: 300$. The chromatographic procedure itself is preceded by treatment with petroleum ether to completely separate asphaltenes. Several fractions were taken from the column by means of subsequent elution with: hexane (alkanes + isoprenoids), benzene (aromatics), ethanol/benzene 1:3 (aromatics + resins) and acetone (oxygen-containing compounds and other heteroatomic) (Table 4).

6) For the isolation of $n+i$-alkanes, the solvent-free hexane fraction was dissolved in propanol and subjected to clathration with urea. Urea adducts normal and iso-alkanes and probably some alkyl benzenes whereas isoprenoids remain in solution. Urea crystals were then dissolved with distilled water and the solution, usually white, was treated again with hexane to extract normal and iso-alkanes.

7) Gas chromatography of $n+i$-alkanes. The last part of the hexane fraction was analyzed by gas chromatography using a "Thermochrom-2" with the following conditions: column $0.4 \times 150 \mathrm{~cm}$ coated with chromosorb containing $3 \%$ SE-30; helium 60 $\mathrm{ml} / \mathrm{min}$; temperature from $150^{\circ}$ to $290^{\circ} \mathrm{C}$ at $10^{\circ} \mathrm{C} / \mathrm{min}$. The resultant gas chromatograms, shown in Figure 2, possess good selectivity of the alkanes.

By multiplying the maximum peak height by the peak width at half height, the peak area was calculated to find the maximum number of the alkanes and their distributions within the range. The odd-even carbon

TABLE 3

Intensities of the Characteristic Reflections of the Minerals Found

\begin{tabular}{|c|c|c|c|c|c|c|}
\hline \multirow[b]{3}{*}{ Core } & \multicolumn{6}{|c|}{ Intensities } \\
\hline & $\begin{array}{l}\text { Montmo- } \\
\text { rillonite }\end{array}$ & $\begin{array}{l}\text { Chlo- } \\
\text { rite }\end{array}$ & $\begin{array}{l}\text { Mica- } \\
\text { illite }\end{array}$ & $\begin{array}{l}\text { Kaoli- } \\
\text { nite }\end{array}$ & Quartz & $\begin{array}{l}\text { Feld- } \\
\text { spar }\end{array}$ \\
\hline & $14 \AA$ & $14 \AA$ & $10 \AA$ & $7.1 \AA$ & $1.82 \AA$ & $3.2 \AA$ \\
\hline 19 & 5 & 3 & 5 & 1 & 3 & 3 \\
\hline 31 & 5 & 1 & 5 & 3 & 3 & 3 \\
\hline 32 & 5 & 1 & 5 & 3 & 3 & 1 \\
\hline 34 & 7 & 1 & 3 & 3 & 3 & 1 \\
\hline 51 & 5 & 3 & 5 & - & 3 & 3 \\
\hline
\end{tabular}


TABLE 4

Authigenic-Mineralogic Forms of Iron and Balance of Organic Carbon Including That Consumed in Reduction Reactions (in wt \% of dry sample)

\begin{tabular}{|c|c|c|c|c|c|c|c|c|c|c|c|}
\hline \multirow[b]{2}{*}{ Core } & \multirow[b]{2}{*}{$\mathrm{Fe}^{2+}$} & \multicolumn{3}{|l|}{ Iron } & \multirow{2}{*}{$\mathrm{C}_{\text {org }}$} & \multicolumn{3}{|c|}{$\mathrm{C}_{\text {org }}^{\mathrm{red}}$ (for reduction) } & \multirow{2}{*}{$\begin{array}{l}C_{\text {org }}^{\text {total }}= \\
C_{\text {org }}+C_{\text {org }}^{\text {red }}\end{array}$} & \multirow{2}{*}{$\beta=\frac{{ }^{E T B B}}{C_{\text {org }}} .100$} & \multirow{2}{*}{$\beta=\frac{\text { ETBB }}{C_{\text {org }}^{\text {total }}} .100$} \\
\hline & & $\mathrm{Fe}^{3+}$ & $\mathrm{Fe}_{\text {pyr }}^{2+}$ & $\mathrm{Fe}_{\text {total }}$ & & $\mathrm{Fe}^{2+}$ & $\mathrm{Fe}_{\mathrm{pyr}}^{2+}$ & Total & & & \\
\hline 19 & 0.301 & 1.028 & 0.937 & 2.267 & 0.53 & 0.016 & 0.755 & 0.771 & 1.30 & 8.11 & 3.31 \\
\hline $19 a$ & 0.344 & 1.233 & 1.639 & 3.216 & 0.53 & 0.019 & 1.320 & 1.339 & 1.87 & 4.90 & 1.40 \\
\hline 31 & 0.339 & 1.596 & 1.114 & 3.050 & 0.57 & 0.018 & 0.897 & 0.915 & 1.48 & 13.51 & 5.20 \\
\hline 32 & 0.160 & 0.944 & 0.838 & 1.945 & 1.77 & 0.009 & 0.675 & 0.684 & 2.45 & 12.99 & 9.39 \\
\hline 34 & 0.196 & 1.134 & 0.665 & 1.995 & 0.95 & 0.011 & 0.535 & 0.546 & 1.50 & 10.95 & 6.93 \\
\hline 51 & 0.226 & 1.929 & 2.050 & 4.205 & 0.30 & 0.012 & 1.650 & 1.662 & 1.96 & 8.33 & 1.27 \\
\hline
\end{tabular}

preference, CPI, in Figure 3 corresponds to the hydrocarbon range of the samples listed in Table 5. Values of CPI for some other ranges also were obtained, but they are cited in the next part of the paper.

8) Determination of the analytical organic carbon $\left(\mathrm{C}_{\mathrm{org}}^{\mathrm{an}}\right) . \mathrm{C}_{\mathrm{org}}^{\mathrm{an}}$ was determined volumetrically by direct combustion of a calcareous-free fraction of the samples (5\% $\mathrm{HCl}$ was used). Since this fraction also was obtained from a bitumoid-free material, the total organic carbon content $\left(\mathrm{C}_{\mathrm{org}}^{\mathrm{an}}\right)$ is equal to the sum of $\mathrm{C}_{\mathrm{org}}^{\mathrm{an}}$

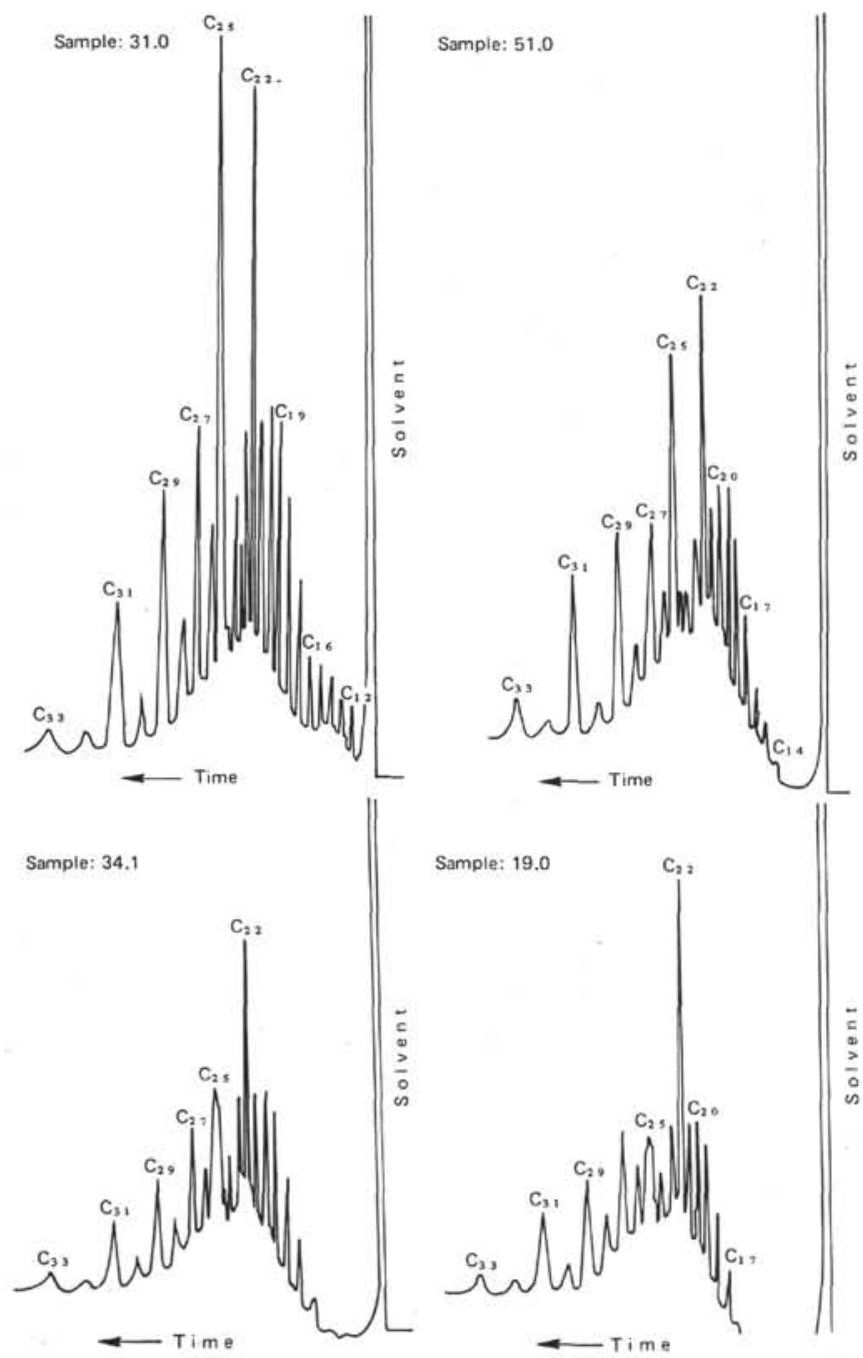

Figure 2. Gas chromatograms of the normal alkanes in the hexane-soluble fraction of bitumoids of samples studied.
$+C_{\text {org }}^{\text {bit }}$ in which approximately $\mathrm{C}_{\text {org }}^{\text {bit }}=0.8 \times$ ETBB (Table 2).

The balance of the organic carbon in Table 4 ( $\mathrm{C}_{\text {org }}^{\text {total }}$ including $\left.\mathrm{C}_{\mathrm{org}}^{\text {ired }}\right)$ was calculated according to Uspenskii's formulas following the steps described earlier (Vuchev et al., 1972).

9) Humic acids, HA, were determined gravimetrically. About $10 \mathrm{~g}$ of a bitumoid-free material were wetted with $100 \mathrm{ml} 2 \% \mathrm{KOH}$ and the mixture was heated, using a water bath. This solubilizes the HA, which next are precipitated with $18 \% \mathrm{HCl}$. The brown residue of $\mathrm{HA}$ was filtered and washed with water plus $1 \% \mathrm{HCl}$ to avoid the peptization and, finally, dried and weighed.

10) Determination of total nitrogen $(\mathrm{N}) . \mathrm{N}$ was determined by sealed-tube digestion technique described by Stevenson and Cheng (1972) with some modification for removing carbonates. Five hundred $\mathrm{mg}$ of sample, previously dried at $105^{\circ} \mathrm{C}$, were placed into a $15 \times 125 \mathrm{~mm}$ Pyrex test-tube, to which $1 \mathrm{ml}$ concentrated $\mathrm{H}_{2} \mathrm{SO}_{4}$ was added. After. 30 min the tube was heated for 2 hours over a steam bath to completely destroy carbonates. An additional $1 \mathrm{ml}$ of a solution containing $2.46 \mathrm{~g} \mathrm{SeO}_{2}$ in $200 \mathrm{ml}$ of concentrated $\mathrm{H}_{2} \mathrm{SO}_{4}$ was added, the tube was sealed, placed into protective steel casing, and the sample was digested at $320^{\circ} \mathrm{C}$ for 4 hours. The proper conditions for digestion were determined experimentally by a series of experiments at different digestion temperatures and durations. After cooling the tube was opened, the mixture transferred to micro-Kjeldahl apparatus and nitrogen determined according to this method. The only modification of this method is the passing of steam for $30 \mathrm{~min}$ through digestion mixture, before addition of $\mathrm{NaOH}$, to remove volatile acidic compounds of the sample.

11) For isolation of amino acids, the samples were extracted with distilled water and hydrochloric acid of increasing concentration. Sediment-water mixtures were refluxed for 40 hours and the water extract was decanted. The precipitate was washed with distilled water two to three times.

The precipitate was refluxed again with $200 \mathrm{ml}$ of $2 \mathrm{~N}$ $\mathrm{HCl}$ for 40 hours. Because of $\mathrm{CO}_{2}$ evolution, $\mathrm{HCl}$ was added slowly. The precipitate was separated by centrifugation and washed two to three times. Finally, the precipitate was refluxed with $6 \mathrm{~N} \mathrm{HCl}$ for 40 hours, centrifugated, and filtrated.

The extracts obtained at this stepwise extraction contain amino acids and also several inorganic 


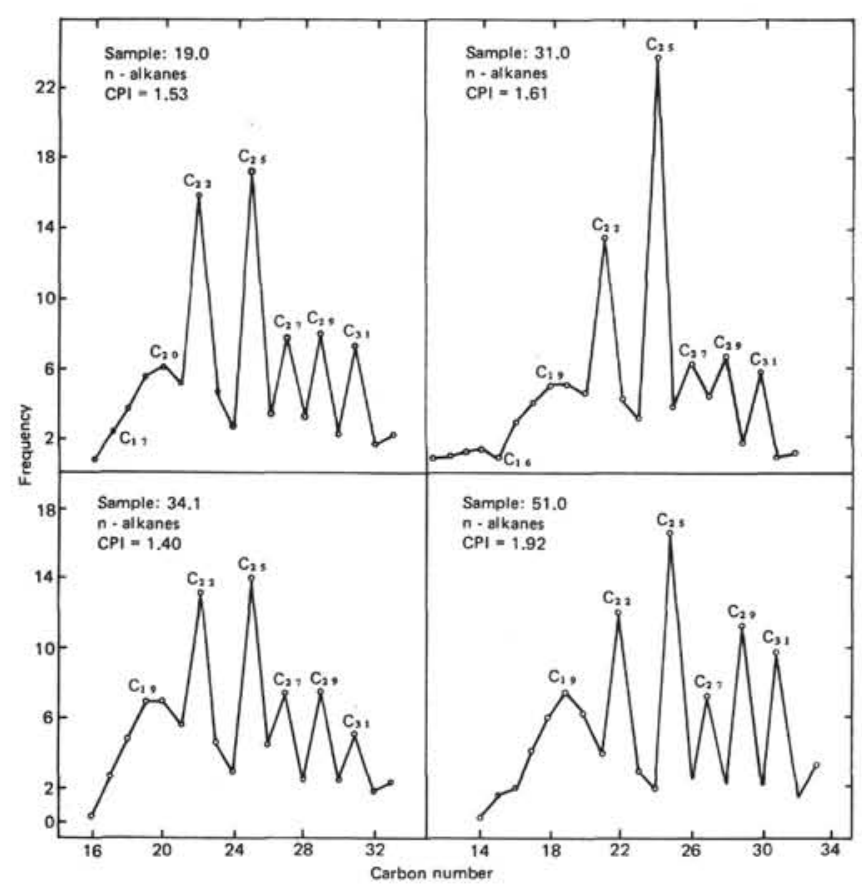

Figure 3. Distributions of the normal alkanes according to the data from gas chromatograms in Figure 2.

TABLE 5

Hydrocarbon Composition of Hexane Fraction

\begin{tabular}{|c|c|c|c|c|c|c|}
\hline \multirow[b]{2}{*}{ Core } & \multirow{2}{*}{ Hexane } & \multirow[b]{2}{*}{ Benzene } & \multicolumn{4}{|c|}{ Fractions (\%) } \\
\hline & & & $\begin{array}{l}\text { Ethanol/ } \\
\text { Benzene }\end{array}$ & Acetone & Asphaltenes & $\begin{array}{c}\text { Total } \\
(\%)\end{array}$ \\
\hline 19 & 18.04 & 29.83 & 19.46 & 8.52 & 21.31 & 97.16 \\
\hline $19 a$ & 19.89 & 24.30 & 18.06 & 9.46 & 25.59 & 97.31 \\
\hline 31 & 8.75 & 21.82 & 23.20 & 10.31 & 33.33 & 97.40 \\
\hline 32 & 4.24 & 37.64 & 22.20 & 11.20 & 21.70 & 96.97 \\
\hline 34 & 11.83 & 19.67 & 16.94 & 6.65 & 41.86 & 96.92 \\
\hline 51 & 13.91 & 25.16 & 21.85 & 14.57 & 21.19 & 96.68 \\
\hline
\end{tabular}

components. To remove these salts, ion-exchange chromatography on Wofatit KPS-200 was applied. The amino acids retained on the resin were eluted with $2 \mathrm{~N}$ and $4 \mathrm{~N} \mathrm{NH}_{3}$. The eluates were evaporated over steam bath and residues containing amino acids were weighed after 24 hours under vacuum over $\mathrm{KOH}$.

The descending method in 20:30:6:24 pyridine- $n$ butanol-glacial acetic acid-water chromatographic system was used to separate and identify the amino acids. The combined paper electrophorese in pyridineacetic buffer at $p \mathrm{H} 5.6$ (1 hour, $1200 \mathrm{~V}$ ) and descending paper chromatography in $n$-butanol-glacial acetic acidwater $(4: 1: 1)$ were also applied.

\section{RESULTS}

The results of this study are listed in Tables 1-7, and are shown in Figures 1, 2, and 3. Therefore, only short comments are necessary.

The sediments are normal calcareous muds with carbonate contents up to $21 \%$ or they are calcareousrich muds according to Zemmels and Cook's (1976) scheme. One exception is Core 34 in which the mud is marly ( $36 \%$ carbonates) (Table 2 ).
TABLE 6

Fractional Composition of the Bitumoids (ETBB)

\begin{tabular}{ccccc}
\hline Core & $\begin{array}{c}\text { Adducts } \\
(\%)\end{array}$ & Range & $\begin{array}{c}\mathrm{C}_{\max } \\
(\%)\end{array}$ & $\begin{array}{c}\text { Isoprenoids } \\
(\%)\end{array}$ \\
\hline 19 & 3.267 & $C_{16}-C_{33}$ & $C_{25}-17.46$ & 14.03 \\
$19 a$ & - & $C_{12}-C_{33}$ & $C_{25}--$ & - \\
31 & 2.947 & $C_{14}-C_{33}$ & $C_{25}-23.65$ & 4.93 \\
34 & 1.860 & $C_{16}-C_{33}$ & $C_{25}-14.30$ & 8.95 \\
51 & 4.503 & $C_{14}-C_{33}$ & $C_{25}-16.25$ & 8.50 \\
\hline
\end{tabular}

According to X-ray diffraction, all of the samples are multicomponent mixtures, containing montmorillonite, mica-illite, chlorite, kaolinite, quartz, and feldspar. Table 3 gives the intensities of the characteristic reflections which are indicative of quantitative relations of these minerals. Montmorillonite and mica-illite are the most abundant minerals.

The DTA thermograms in Figure 1 substantiate the $\mathrm{X}$-ray data in general, but the thermal characteristics of the mica-illite are even more definite. Endothermic reactions of clay minerals within the $100^{\circ}-200^{\circ} \mathrm{C}$ range are likely reduced due to exothermic reactions in the organic matter. Also, this may exaggerate the natural effects of the minerals in the interval from $300^{\circ}$ to $460^{\circ} \mathrm{C}$.

Two samples from different parts of the same interval, 19 and 19a, have close values of the basic geochemical indexes and can be used as an index of the precision of the experiments. Together with Core 31, which originates from another site and contains more terrigenous constituents, the samples have equal content of $\mathrm{C}_{\text {org }}$-about $0.5 \%$. The maximum of $1.77 \%$ Corg corresponds to Core 32 , whereas the minimum of $0.3 \% \mathrm{C}_{\text {org }}$ corresponds to Core 51 . The geochemical distinction of Core 32 from the other ones can be seen in almost all of the geochemical indexes-maximal content of ETBB, maximum $\mathrm{N}$ content (Table 2), minimal content of $\mathrm{Fe}_{\text {total }}$ and almost all of its forms (Table 4), minimum of the hexane and maximum of the benzene fractions (Table 5), minimum of ETBB (A + C) and corresponding maximum of the ratio ETBB $/$ ETBB $(A+C)$ (Table 2). The only sedimentological differences of this sample from the others can be found in its higher content of diatoms.

In spite of the young geological age of the sediments, bitumoids are the most significant extractable component and they considerably exceed the HA content which is below $0.04 \%$ (Table 2).

The content of $\mathrm{Fe}_{\text {total }}$ and of its authigenicmineralogic forms is noteworthy. A common peculiarity is the close $\mathrm{Fe}^{2+}$ contents, which range ove a factor of 2. The minimum of $\mathrm{Fe}^{2+}$ may be related to carbonate or leptochloritic forms and the close contents of $\mathrm{Fe}^{3+}$ and $\mathrm{Fe}_{\text {pyrr. }}^{2+}$ Moreover, the latter seems rather strange taking into account the stagnation of the Black Sea and the very rich organic content of the sediments which should carry out a diagenic reduction of $\mathrm{Fe}^{3+}$. The total organic carbon (Table 4) contents are equal or very close. These are also informative for the richness of the sediments in source organic matter. 
TABLE 7

Contents of Desalted Water and HCI Extracts and Noncarbonate Residue in Samples Studied (in wt \% to dry sample)

\begin{tabular}{lcccccccc}
\hline & \multicolumn{3}{c}{ Water } & \multicolumn{2}{c}{$2 N \mathrm{HCl}$} & \multicolumn{2}{c}{$6 \mathrm{~N} \mathrm{HCl}$} & \multicolumn{2}{c}{ Noncarbonate Residue } \\
Core & $(\mathrm{g})$ & $(\%)$ & $(\mathrm{g})$ & $(\%)$ & $(\mathrm{g})$ & $(\%)$ & $(\mathrm{g})$ & $(\%)$ \\
\hline 19 & 0.0523 & 0.147 & 0.0900 & 0.253 & 0.0841 & 0.236 & 21.74 & 61.05 \\
$19 \mathrm{a}$ & 0.0669 & 0.190 & 0.0681 & 0.193 & 0.0969 & 0.275 & 19.48 & 55.43 \\
31 & 0.0521 & 0.155 & 0.0798 & 0.237 & 0.0799 & 0.238 & 20.08 & 59.76 \\
32 & 0.0593 & 0.237 & 0.0702 & 0.280 & 0.0740 & 0.294 & 16.40 & 65.21 \\
34 & 0.0177 & 0.054 & 0.1720 & 0.521 & 0.1612 & 0.476 & 13.31 & 40.36 \\
51 & 0.0505 & 0.013 & 0.0577 & 0.147 & 0.1112 & 0.282 & 23.42 & 60.00 \\
\hline
\end{tabular}

The degree of bituminosity, $\beta$, is maximal for Cores 31 and 32 , and can be considered as expressing both the lower stage of the diagenetic transformation of the organic matter and the source, probably sapropelic, of the organic material (Table 4). The influence of the $C_{\text {org }}$ balance over the degree of bituminosity is clear expressed by $\beta^{*}$ which differs significantly from $\beta$.

Table 5 shows that the greatest aliphatic character of the bitumoids occurs in Cores 19 and $19 \mathrm{a}$ and the highest aromatic bitumoid composition in Core 32 . Core 34 contains the largest value of asphaltenes, i.e., high molecular structures with slight variations of aliphatic, aromatic and resinous components from the other samples. The samples have approximately equal losses of about $3 \%$ due to the adsorption of the most polar compounds by the column.

The adducts, including normal and iso-alkanes and likely some alkyl benzenes, comprise the smaller part of the hexane fraction (Table 6) in comparison with the isoprenoids. The latter compounds suggest the youngness of bitumoids. Core 51 , from the greatest depth, is the richest in alkanes, although the apparent increase at adduct portions with depth is equivocal. Apparently, the 300-meter depth interval of the samples is too small for the development of stage differences in the evolution of the organic matter. This statement is also supported by the similarities of the gas chromatograms (Figure 2) and of the similarities of normal alkane carbon numbers: the same maximal number, $\mathrm{C}_{25}$, followed by $\mathrm{C}_{22}$ and with very close CPI values showing sharp odd to even predominance (Figure 3 ). There are two separate intervals on each of the distributions-from $\mathrm{C}_{\min }$ to $\mathrm{C}_{24}$ and from $\mathrm{C}_{24}$ to $\mathrm{C}_{\max }$. These distinctions can be seen in the values of CPI for samples:

\begin{tabular}{lccccc} 
Sample & $C_{\min }-C_{21}$ & $C_{\min }-C_{23}$ & $C_{24}-C_{\max }$ & $C_{22}-C_{\max }$ & $C_{23}-C_{\max }$ \\
\hline 19 & 1.72 & 0.66 & 4.62 & 1.70 & 3.16 \\
31 & 1.21 & 0.71 & 3.51 & 1.80 & 2.66 \\
34 & 1.24 & 0.80 & 3.21 & 1.79 & 2.50 \\
51 & 1.18 & 0.74 & 3.88 & 2.44 & 3.16
\end{tabular}

$\mathrm{ETBB}(\mathrm{A}+\mathrm{C})$ predominates over ETBB not only in quantity but also by its fractional composition. First, the asphaltenes of ETBB $(A+C)$, which range between $40 \%$ and $69 \%$ and are the main fraction of any of these bitumoids, prevail over the asphaltenes of ETBB, which are not the main component of all samples and are for the most $42 \%$ (Table 5). Secondly, the hexane, and particularly, the benzene fractions of ETBB predom- inate significantly over the $\operatorname{ETBB}(A+C)$ fractions. Thirdly, the last two fractions-ethanol/benzene and acetone-are close to each other for both bitumoids. In spite of all geochemical differences listed, the alkanes of ETBB and ETBB $(A+C)$ have the same predominant carbon number, namely $\mathrm{C}_{25}$.

Using paper chromatographic separation and identification, the following amino acids occurred in all samples: Gly, Ala, Val, Leu (Ile), and Asp. Also, in the water extracts of Cores 19a and 32, were two other ninhydrin-positive substances with $\mathrm{Rf}$ values between those of valine and leucine. To consider the possibility of overlapping and masking of some of the spots at the chromatographic separation, a combined paper electrophoretic with paper chromatographic separation was further applied. In this case the following amino acids were identified: (a) in the water extracts-minor quantities of Gly and Ala and traces of Val, Leu (Ile), and Asp; (b) in the $2 \mathrm{~N} \mathrm{HCl}$ extracts-the same amino acids but in larger amounts, particularly, glycine. Two other spots were also obtained, one of which, according to its $\mathrm{Rf}$ value, corresponds to Glu, but the other one did not fit with any of the amino acids standards. Its location on the combined paper electrophoregram/chromatogram can only be used as evidence for the slightly basic character of the substance; (c) in the $6 \mathrm{~N} \mathrm{HCl}$ extracts, very strong spot for Gly, strong spots for Ala and Pro, spots of middle strength for Val, Leu (Ile), Asp, and Guy, weak spots for Thr and Lys. Moreover, there were five other weak spots of basic character which probably belong to some amines obtained by decarboxylation of the amino acids.

The estimated approximate quantitative composition of the amino acids in the $6 \mathrm{~N} \mathrm{HCl}$ extracts is as follows: if the most intensive spot of Gly is 100 , the intensities of the other spots may be estimated as Ala $=70$, Leu (Ile) $=40, \mathrm{Val}=30, \mathrm{Glu}=30, \mathrm{Asp}=25, \mathrm{Thr}=20$, Lys $=$ 10 , and unidentified basic spots $=10-20$. The relations of the amino acids in the $2 \mathrm{~N} \mathrm{HCl}$ extracts are analogous.

These results and those in Table 7 show that the amount of amino acids in water extract, as expected is smaller than that in $2 . N \mathrm{HCl}$ and $6 \mathrm{~N} \mathrm{HCl}$ extracts.

The fact that a considerable part of amino acids can be extracted only by continued treatment with, $6 \mathrm{~N}$ $\mathrm{HCl}$ in particular shows that the amino acids and the higher molecular-weight degradation protein products, respectively, are intimately connected with the inorganic matrix. The carbonates play a definite role in this matrix. 


\section{REFERENCES}

Stephanov, D., Grozdanov, L., and Matsev, T., 1968. X-ray camera of small angles and its application in clay mineral studies: Geol. Inst. Bulg. Academy of Sci., ser. Geochem. Mineral. and Petrogr. Bull,, v. 17, p. 189-200.

Stevenson, F.J. and Cheng, C.-N., 1972. Organic geochemistry of the Argentine Basin sediments: carbonnitrogen relationships and Quarternary correlation: Geochim. Cosmochim. Acta, v. 36, p. 653-671.
Vuchev, V.T., Howells, W.G., and Burlingame, A.L., 1972. The presence and geochemical significance of organic matter extractable from Jurassic and Triassic sediments of Northern Bulgaria. In Advance in organic geochemistry: Oxford (Pergamon Press), p. 365-386.

Zemmels, I. and Cook, H.E., 1976. X-ray mineralogy data from the Nazca Plate-Leg 34 Deep Sea Drilling Project. In Yeats, R.S., Hart, S.R., et al., Initial Reports of the Deep Sea Drilling Project, Volume 34: Washington (U.S. Government Printing Office), p. 589-600. 